\title{
A Study of Written Errors of Iranian Learners: A Systematic Review
}

\author{
Ali Akbar Khansir \\ Bushehr University of Medical Sciences, Bushehr, Iran \\ Farhad Pakdel \\ Shiraz University of Medical Sciences, Shiraz, Iran
}

\begin{abstract}
The collection of this systematic article was an attempt to show a survey of current activities in the field of error analysis in English language from 2012 to 2018 in Iran. In the country, English is being taught as Foreign Language from middle school. Khansir and Gholami Dashti (2014) mentioned that English accepted as language to pass in the examination. However, English system in this country often put on formal accuracy and teachers focus on the teaching of English grammar in their classes. Error analysis approach has been a widely discussed topic for more than 60 years over the world. However, all the findings of this paper from previous research works on error analysis can be good reasons in order to guide and help reduce such errors in the written language of Iranian students in EFL setting and the results of this work can also be used to as a guide for English learners over the world. This article identifies and presents the major reasons leading to the English written errors among the Iranian learners. Finally, it reports the effective strategies and suggestions for helping the students to improve their English language. The researchers of this study studied 178 papers in this process and 37 of the papers were relevant.
\end{abstract}

Index Terms - error analysis, contrastive analysis, EFL learners, English language teaching and learning, English as foreign language

\section{INTRODUCTION}

Issues concerning error analysis approach in English language learning have been widely discussed for more than sixty years. Error analysis approach is still frequently and efficiently used in English language learning today. There are also studies on the relationship between error analysis and English language learning in EFL setting. It is important, therefore, to come back where knowledge of the history of Error analysis approach if we want to understand better and easier why have EFL learners committed errors in their target language. Khansir (2012a) reported that error analysis approach appeared as reaction to Contrastive Analysis Theory in the sixties in order to reveal that errors committed by learners in target language were not only because of native language interference. However, the perspective of error analysis is provided by Corder's paper "The Significance of Learner's Errors in 1967. From this article we turn back to see that learner's errors are seen as an integral part of language learning and provide a good feed back to the linguist, teacher, and student interested in the process of target language learning in ascertaining. Khansir (2008a) added that the value of error analysis is that it is a systematic analysis can be used in order to guide the language teacher, learner and the course designer along with the producer of the teaching materials to get know their target language. Corder (1974) followed this discussion about the value of error analysis in language teaching and described that systematically analyzing errors committed by language learners makes it possible to determine areas that need reinforcement in teaching. Khansir (2008b) argued that error analysis enables teachers to find out the sources of errors and take pedagogical precautions toward them. Thus, the analysis of learner's language has become an essential need to overcome some questions and propose solutions regarding different aspects.

As mentioned above, in recent years, error analysis approach has become increasingly popular in second and foreign language teaching circles. So, one of the main aims of error analysis approach is to identify students ' problems and relate to the ideas of reflective and critical approach in order to consider worth looking into more deeply and systematically. The central idea of error analysis approach is to improve the language errors based on the information that found in the action of research. What we say is that the characteristics of error analysis approach can be described and known with specific methods of language teaching or language skills. Therefore, this approach is viewed as mainly with general rules and principles and derived from knowledge of sources in target language. It is time now to turn our attention to error analysis. Language teachers should use it to help and improve their students' target language in EFL or ESL settings.

In many countries such as Iran, language teachers have interested in knowing more about their students' errors in English language. The English language teachers in Iran (English as EFL setting) would like to be more effective teachers who provide the beat learning strategies for their students. Error analysis approach can be an important valuable strategy to extend their teaching English language skills and help them gain more understanding of their work 
as English teachers in their classrooms. Finally, from a point of view of training perspective in error analysis approach, the language teacher should be seen as an expert, as the source of information and ideas. His or her functions are to provide suggestions in order to solve problems of his/ her learners and sometimes he/he should intervene and point out better ways to the treatment of skills, techniques are particularly required in target language. However, error analysis approach is part of applied linguistics that has been going on in EFL and ESL generally for several decades.

Now let us give a brief overview of the historical development of Applied Linguistics, because error analysis has been appeared as a branch of applied linguistics. Applied linguistics came back to the year of 1940 and this term was developed to label a course applying a so-called "scientific approach" to teaching foreign languages (Khansir, 2013a). Wilkins (1999, p 7) mentioned that" in a board sense, applied linguistics is concerned with increasing understanding of the role of language in human affairs and thereby with providing the knowledge necessary for those who are responsible for taking language -related decisions whether the need for these arises in the classroom, the workplace, the law court, or the laboratory." Varshney (1998, p. 313) added that "applied linguistics is the collective term for the various applications of linguistics (and phonetic) scholarship to related practical fields -foreign language teaching, lexicography, translation, speech pathology and therapy, error analysis, etc." We can conclude that the purpose of applied linguistics is to solve some problems in the language teaching and learning.

\section{METHODOLOGY}

\section{A. Materials}

The present paper seeks to analysis the written errors in English language by Iranian researchers. However, in Iran, English is being taught as a Foreign Language with a view to teaching English grammar. Therefore, the examination system in EFL classrooms often put a premium on formal accuracy. In this study, the thirty seven articles have analyzed the error analysis approach collected from reputable Academic Journals such as Applied Linguistics, English Language Teaching and Linguistics. This paper focuses on only the written errors in EFL setting in Iran.

\section{B. Inclusion/Exclusion Criteria of This Study}

The list below illustrates the articles which were included based on the following criteria:

1. The articles were conducted in Iran where English used as a foreign language.

2. The articles investigated the written errors of English language.

3. The articles were published between 2012 and 2018.

4. The articles were peer-reviewed journal publications.

So, the research papers were excluded based on the following criteria:

1. The articles were not conducted in Iran where English used as a foreign language.

2. The articles did not examine the written errors of English language.

3. The articles were published before 2012 or after 2018.

4. The articles were not peer-reviewed journal publications.

\section{RESUlTS AND DisCUSSION}

Discussions about applied linguistics have always been colored by debates on fundamental issues in human language learning more generally and English language in particular. One of the issues debates of applied linguistics is error analysis approach. There are many research scholars who have worked on error analysis approach in EFL setting in Iran, their works are considered in the following paragraphs.

Sattari (2012) analyzed the written grammatical errors of Iranian students. They argued that the most errors were due to the influence of mother tongue in their research. Khansir (2012b) investigated the written errors of Iranian students in the field of syntax. He retorted that the Iranian students caused 2841 errors in English language. Thus, he pointed out that learning strategies and teaching programs are the main reason of the learners' errors in this research work. Based on this paper, the Iranian students need to be taught and encouraged more than what is being done in that time. Hariri (2012) examined the morphosyntactic errors of Persian students in Iran. All the students were female. They were asked to write an essay in English language. The findings of this research paper indicated that the female learners had more errors in the use of prepositions and then the use of articles. He added that they had fewer errors in the use of relative clauses and relative pronouns and wrong use of verbs. Therefore, Inter-lingual errors were the main category of errors and then category of transfer was the minimum errors in this study. Sabzalipour (2012) tested English sentences of ten Iranian students through translation strategy. She argued that the students made errors in English. Thus, the errors of this study include Inter-lingual errors' $31 \%$ and 'Intra-lingual errors ' 63\%. She said that first language transfer was major cause of the errors among the students. Jalali and Shojaei (2012) obtained the developmental and fossilized propositional errors in the writing of Iranian learners in their compositions papers. They understood that the learners need to be given to the teaching of English propositions works in order to improve the students' works. According to the research of Iranian learners' errors was presented by Kafipour and Khojasteh in 2012. They argued that the sampling of their research work committed more developmental errors in their writing. Jabbari and Fazilatfar (2012) reported that 
the most errors of Iranian students in this study were due to first language (Persian language). They added that the errors including grammar, lexical and phonological.

Khansir (2013b) considered the Iranian written errors in target language (English). Based on the result of his research paper, the participants made 3045 written errors in English language. Therefore, this study showed that the learners did not have good knowledge in supplying the correct rules of English writing. He added that the Iranian students need more practice in English writing and the Iranian English teachers should arrange the remedial materials on the basis of the degree of frequency recurrence. Tafazoli et al (2013) used translation strategy to get Syntactic and Morphological errors of Iranian EFL undergraduate students. They selected five hundred students for collecting data to analyses their work. Their project showed that the most errors of the learners were in use of articles in Syntactic and Morphological errors in their translation. After analyzing errors of Iranian intermediate students by Barzegar researcher in 2013, He recognized that the participants of the study caused more errors in Intralingual. Eftekhar and Nouraey (2013) found grammatical errors of the students were the most errors among the others types of the errors in this study. Boroomand and Rostami Abusaeedi (2013) investigated one hundred advanced Iranian students and then the participants were divided into two groups: fifty male and fifty female. This study indicated that the group of female committed more frequency errors in their writing. In the study of Khansir and Shahhoseiny in 2013, Iranian students made errors in three grammatical items such as Tenses, Active and passive forms and articles in English writing. Their work showed that the students 'errors were systematic. In fact, they need more practice and get more knowledge of English grammar rules.

Solati (2014) studied the spelling errors of 40 Persian learners. The outcome of this research paper showed that the causes of spelling errors were committed by the Persian students were due to lack of knowledge of phonology, orthography, morphology, and mental orthographic images. He added that first language interference, overgeneralization, ignorance of rule restriction, and homophone confusion were the sources of errors in this study. Rahimi and Tafazoli (2014) analyzed the written errors of undergraduate EFL learners in Islamic Azad University, Iran. The findings of their study indicated that the Iranian EFL students committed the errors in the use of articles, verb groups, preposition, and wrong use of negative construction. They added that the articles errors were the most errors in this project. They suggested that the teachers should apply more flexible strategies in order to correct the students' errors and thus, they apply language teaching and learning strategy as a classroom strategy to improve the language learners are known as vital roles of the teachers. Yousefi et al (2014) examined the prepositions errors of Iranian EFL learners in English language. The outcome of the study showed that the prepositions errors made by the learners were due to both Inter-lingual and Intra-lingual interferences. They added that English prepositions of 'in', 'at' and' to' cause the most frequent errors in this project. They suggested that students are more needed to teach preposition to them. Their teachers should raise the learners' knowledge of prepositions rules. Omidipour (2014) investigated errors of 40 Iranian learners in English writing. Thus, the errors of this study were categorized in three items such as Syntacticomorphological Errors, Orthographic Errors, and Lexico-semantic Errors. His results showed that first language of the learners is one of the main reasons of errors in this paper. He hopes that this study can help teachers for teaching English for their students. Satariyan and Mohseni (2014) set out a study on common errors in Iranian pupils writing. 190 Iranian pupils were selected for data collection. They asked the learners to write English essay. This study showed that the pupils had problems in Organization, mechanics and syntax and also they made vocabulary and discourse errors. According to the study of Rahmanifard and Yarmohammadi in 2014, the main reasons of learners' errors were poor linguistic competence. The errors of this paper were divided into five categories: vocabulary, phonological awareness, morphological and semantic relationships, knowledge of orthography, and mental orthographic images.

Golshan and Reigani (2015) studied the spelling errors of Persian female students of English in Iran. In this study, the Persian learners' spelling errors were related to a wrong use of vowels and pronunciation. They argued that the Iranian students had not good knowledge to recognize the actual sound system of English and the learners used their mothertongues in their spelling, so they used the wrong letters. They suggested that the teachers should apply the following points in order to help their learners to improve their English spelling in writing:

1) teach more the rules of spelling; 2) drill and practice on spelling rules: suffixes and prefixes more; 3 ) encourage their students to read more reading materials; and 4) inform their students apply English spelling words loudly. Beheshti (2015) analyzed the written grammatical errors of intermediate, upper-intermediate and advanced Iranian students. In this study, the participants were selected based on the results of Oxford Proficiency Test. All the participants were selected by random sampling in this project. The students made some developmental errors and then they committed the most frequently occurring prepositional errors in their writing. Thus, in this study, the sources of the errors can be Interlingual and Intra-lingual and etc. Abusaeedi and Asghar (2015) conducted the written errors on one hundred advanced students in Iran. Their study showed that the sources of the errors made by Persian students were resulted from partial learning and imperfect mastery of the target language and interference of mother tongue. They suggested that this type of study with more participants should be more done and they believed that different learning strategies as well as teaching methods and techniques should be investigated with regard to the kinds of errors at different proficiency levels. Davoudi et al (2015) reported the written errors of a group of Persian thirty four undergraduate students in Iran. The findings of this project paper indicated that Iranian EFL students committed errors in paragraph writing such as content and organization, support and development, cohesion and coherence, structure, vocabulary and mechanics. They suggested that the feedback and commentary of the instructor on these aspects of the written errors in paragraph writing 
should be examined. Tajareh and Khodareza (2015) dealt with the effect of English adjective by Error Analysis on the knowledge of Iranian pupils. They concluded that ways of using the error analysis had positive effect on L2 adjective. The results of study of Forutan and Mehranpour in 2015 showed that the errors of preposition were due to transfer between first and second language of the learners. Shahhoseiny is one of Iranian researchers studied on Iranian students' writing. She said that the results of her research work showed that the learners had large errors in paragraph writing and their errors were due to lack of knowledge of paragraph writing. She believed that the learners need more work in this area (2015).

Khansir and Ilkhani (2016) reported on the written grammatical errors such as tenses, voice (active and passive), and prepositions which were used in the form of multiple - choice tests. They selected one hundred Iranian students at undergraduate level in Bushehr city, Iran. The findings of this research indicated that the learners did not have prefect in using of English tenses, passive and active voice, and preposition in this research work. What the paper is saying is that there is a significant difference in types of written grammatical errors by the learners in target language. Solati (2016) conducted quantitative and qualitative methods for the collection of data at North Khorasan University of Medical Sciences in Iran. He studied the problems of the students in the use of English present simple tense. He used multiplechoice items as the test of this research paper for the judge of the learners' knowledge in the use of English present simple tense. The findings of this paper showed that the students were not aware of English present simple tense rules and they had confusion over a large number of verb forms and then they had not good knowledge in the use of the auxiliary verbs. He suggested that the use of Intra-lingual techniques in order to overcome the mentioned problems in this study. He added that both Inter-lingual and Intra-lingual interference strategies were the sources of errors in this research. Khansir and Hajivandi (2016) examined the written errors of one hundred sixty Iranian Medical students. Outcome of this project showed that the students have not perfected in using of English essay writing and structure of paragraph writing in this project. Dehbashi Sharif and Hassani (2016) pointed out English grammatical errors of Iranian researchers through the English translation of their abstracts of Persian articles in many Iranian academic journals. According to this study, grammatical errors such as prepositions, plural morpheme, articles, and parts of speech were repeated in most of the Iranian translated articles.

Khansir and Pakdel (2017) studied English clauses errors of Iranian learners at undergraduate level in Bushehr city. The subjects were in the age range of 20 to 27. They made 594 errors in English clauses. The findings of the research article showed that Iranian students had not good knowledge in this area and they suggested that they need enough drills to be conducted by teachers for them in order to increase their knowledge of English clauses and reduce their errors. Khoshsima and Banaruee (2017) carried out an analysis on English common errors committed by Iranian EFL students. They selected 80 Persian learners for the purpose of data collection in their research project. Their study showed that first language interference was the most major important source of the errors in the students' English grammar and vocabulary. They added that the least common errors were various subtypes of punctuations in this work. Thus, the most common developmental errors committed by the learners were spelling. Pouladian et al (2017) investigated the written errors of a group of adult Iranian EFL learners in Iran. The outcome of this paper revealed that the learners committed the very common grammatical mistakes in verb tenses and thus, they made the most common categories of errors in cohesion and coherence and lexical sub-categories, relative clauses and incorrect use of target lexical item.

Bahrpeyma and Ostad (2018) conducted a study on English errors in the compositions of Iranian learners who were selected from two language institutes in the cities of Rasht and Bandar Anzali in the north of Iran. The results of this research work showed that the students committed the most frequent types of English errors in the area of Articles, Capitalization, Wrong verb tense and Subject/verb agreement. In addition, the most of source of errors was due the interference of their mother tongue. They suggested that the details of errors should be more investigated. For better work, they added that the English writing of undergraduate students will be investigated in the future research in those areas. Momenzade1 et al (2018) analyzed the written errors of medical students who were studied in Shiraz University of Medical Sciences. The findings of this project showed that the most consistent errors both in test and retest were omission. They suggested that their teachers should more focus on learners' specific areas of weakness and try to improve them. They should more focus on teaching methods and learning and teaching strategy. Salehil and Bahrami (2018) reported the written common errors of Iranian authors in forty scientific articles were written by students that were edited by an editing team at Sharif University of Technology, Languages and Linguistics Center. They investigated eight types of errors such as errors in word usage, articles, preposition, conjunction, and tense, errors in word order active-passive structures and subject-verb agreement. Therefore, the maximum errors committed in this paper were word usage $(36.2 \%)$ and thus, the minimum errors made in this research were subject-verb agreement $(0.7 \%)$. They added that the main reason for the errors can be related to the similarity or difference between Persian and English. The study of Yousefi in 2018 showed that Iranian students committed more errors in using English articles and present perfect tense. She believed that the learners should be taught the rules of writing and grammar, before they start writing.

\section{CONCLUSION}

As results of this research paper, are carried out in EFL setting in Iran by the researchers mainly with the purpose of solving English problems in EFL classroom and improving the teaching and learning English process. So, one of the 
main aims of this paper is to help in order to improve the teaching practice and learning strategy. This paper also sets out to help teachers develop sensitivity in encouraging them to develop a positive attitude towards their learners' errors. Thus, we hope that the suggestion of this paper will help for finding ways of correcting errors of the students.

The second stage of this paper is to decide which changes what we need to make in our teaching English through errors. Thus, one reason to change the way we teach is to solve learning problems. Problem-solving is the usual way that teachers along with syllabus designers make decisions about what to change in their teaching. However, it is also possible to explore teaching through error correction. Khansir and Pakdel (2018) mentioned that it is possible to develop the competence of pupils in target language through error correction. This study informs us that learning and teaching strategies and interference of mother tongue were the other reasons for learners' errors. Basically, the basic structure of this paper is to create a good interaction in English in meaningful ways through error analysis so that EFL learners can make progress in learning English. In addition, a successful project of error analysis is one that uses both contrastive and error approaches as one of the main subjects of applied linguistics. Finally, according to Khansir and Pakdel (2019), many researches on error analysis indicate that learner's errors are an integral part of language learning can be used as great strategy in teaching second and foreign language.

\section{REFERENCES}

[1] Abusaeedi, R. \& Asghar, A. (2015). A quantitative analysis of Iranian EFL learners' sources of written errors. International Journal of Research Studies in Language Learning, 4(1), 31-42.

[2] Bahrpeyma, M., \& Ostad, O. (2018). Error analysis of composition writing: A case of Iranian EFL learners. International Journal of Research Studies in Language Learning, 7(2), 101-112.

[3] Barzegar, M. (2013). Persian EFL students' error analysis. Asian Journal of Social Sciences \& Humanities, 2(4), $322-334$.

[4] Beheshti, Z. (2015). Syntactic Analysis of Errors in Iranian EFL Learners' Written Productions. Journal of Applied Linguistics and Language Research, 2 (6), 1-12.

[5] Boroomand, F \& Rostami Abusaeedi, A. (2013). A gender-based analysis of Iranian EFL learners' types of written errors. International Journal of Research Studies in Language Learning, 2 (5), 79-92.

[6] Corder, S.P. (1967). The Significance of Learners' Errors. IRAL, 5(4), 161-170.

[7] Corder, S. P. (1974). Error Analysis. In J. P. B. Allen and S. Pit Corder (eds.) Techniques in Applied Linguistics (The Edinburgh Course in Applied Linguistics:3). London: Oxford.

[8] Davoudi,M., Moulavi Nafchi, A., \& Mallahi, O. (2015). A Macro-level Error Analysis of Iranian Undergraduate EFL Learners' Performance on Writing Tasks. Journal of Studies in Education, 5(4), 222-241.

[9] Dehbashi Sharif, F \& Hassani, M. (2016). Error analysis of the Grammatical Patterns in the English Translation of the Abstracts of the Persian Articles in the Iranian Published Academic Journals. ELT Voices- International Journal for Teachers of English, 7 (1), 1-10.

[10] Eftekhar, M. \& Nouraey, P. (2013). Commercial Translation Error Analysis: A Case Study of Iranian Products. Linguistics and Literature Studies, 1(2), 55-60.

[11] Forutan, A. \& Mehranpour, F. (2015). On the Iranian EFL Learners' Sources of Errors in the Production of Propositions. Journal of Language, Linguistics and Literature, 1 (4), 120-126.

[12] Golshan,M \& Reigani, P. (2015). Analysis Spelling Errors: Iranian Female Beginner Learners of English. MJAL, (7)2, $174-188$.

[13] Hariri, M. (2012). Taxonomy of Morpho-Syntactic Errors and Error Analysis. Research Journal of Applied Sciences, Engineering and Technology 4(22): 4856-4860.

[14] Jabbari ,A.A, \& Fazilatfar, A.M. (2012). The Role of Error Types and Feedback in Iranian EFL Classrooms. International Journal of English Linguistics, 2 (1), 135-148.

[15] Jalali,H \& Shojaei, M. (2012). Persian EFL Students' Developmental versus Fossilized Prepositional Errors. The Reading Matrix, 12(1), 80-97.

[16] Kafipour, R., \& Khojasteh, L. (2012). A comparative taxonomy of errors made by Iranian undergraduate learners of English. Canadian Social Science, 8(1), 18-24.

[17] Khansir,A.A. (2008a). Syntactic Errors in English Committed by Indian Undergraduate Students. Language in India, 8(7), 1-11.

[18] Khansir, A, A. (2008b). Place of Error Analysis in Language Teaching. Indian Lingustics. 69 (1-4), 195-202.

[19] Khansir, A.A., (2012a). Error Analysis and Second Language Acquisition. Theory and Practice in Language Studies, 2: $1027-$ 1032.

[20] Khansir, A.A. (2012b). Study of The Syntactic Errors Committed by EFL And ESL Learners At Under Graduate Level. Indian Linguistics, 73 (1-4), 89-100.

[21] Khansir, A.A. (2013a). Applied Linguistics and English Language Teaching. Middle-East Journal of Scientific Research, 15 (8):1140-1146.

[22] Khansir,A.A. (2013b). Error Analysis and Second Language Writing. Theory and Practice in Language Studies, 3 (2), $363-370$.

[23] Khansir,A.A. \& Shahhoseiny, H. (2013). The Study of Written Errors of EFL Pre-university Learners. Journal of Language Teaching and Research, 4 (6), 1253-1258.

[24] Khansir A.A., \& Gholami Dashti, J. (2014). The Effect of Question-Generation Strategy on Iranian EFL Learners' Reading Comprehension Development. English Language Teaching, 7(4), 38-45.

[25] Khansir, A.A., \& Ilkhani, M. (2016). A Study of Written Grammatical Errors of Iranian EFL Learners at Undergraduate Level. Theory and Practice in Language Studies, 6(2), 268-273.

[26] Khansir, A. A, \& Hajivandi, A. (2016). Iranian Medical Learners and Their Errors. Modern Journal of Language Teaching Methods, 6(1), 416-426.

[27] Khansir,A.A., \& Pakdel, F. (2017). Study of English Clauses Errors in Syntactic Structures of Iranian Students. Language in India, 17(4): 103. 
[28] Khansir, A. A., \& Pakdel, F. (2018). Place of Error Correction in English Language teaching. Educational Process: International Journal, 7(3), 189-199.

[29] Khansir, A. A., \& Pakdel, F. (2019). Contrastive Analysis Hypothesis and Second Language Learning. Journal of ELT Research, 4(1), 35-43.

[30] Khoshsima, H, \& Banaruee, H. (2017). L1 Interfering and L2 Developmental Writing Errors among Iranian EFL Learners. European Journal of English Language Teaching, 2(4):1-15.

[31] Momenzade1, Z., Khojasteh,L., \& Kafipour, R. (2018). An Analysis of the most Consistent Errors in English Composition of Shiraz Medical Students. Pertanika J. Soc. Sci. \& Hum. 26 (2), 1189 - 1202.

[32] Omidipour, M. (2014). An Analysis of Errors in Writing among Adult Persian Learners of English. International Journal of Language Learning and Applied Linguistics World (IJLLALW), 5(3), 176-187.

[33] Pouladian, N., Sadegh Bagheri, M., \& Sadighi, F. (2017). An Analysis of Errors in Writing Skill of Adult Iranian EFL Learners Preparing for the IELTS. International Journal of English Linguistics, 7(3), 85-96.

[34] Rahimi, A., \& Tafazoli, D. (2014). Error Analysis In Technology-Mediated Communication: Focus On EFL Writing In Synchronous And Asynchronous Modes Of Communication. Procedia - Social and Behavioral Sciences, 136, 66 - 69.

[35] Rahmanifard, N., \& Yarmohammadi, L. (2014). Cross-Linguistic Examination of Spelling Errors Made by Iranian EFL Learners. Journal of Studies in Learning and Teaching English, 2 (6), 149-180.

[36] Sabzalipour, B. (2012). Error Analysis on Students' Persian - English Translation. Asian journal of social sciences \& humanities, 1(4), 171-176.

[37] Salehi1, M., \& Bahrami, A. (2018). An error analysis of journal papers written by Persian authors. Cogent Arts \& Humanities, $5,1-16$

[38] Satariyan, A and Mohseni, A. (2014). Writing Skill and Categorical Error Analysis: A Study of First Year Undergraduate University Students. IJRELT, 2(1), 20-30.

[39] Sattari, A. (2012). An analysis of grammatical errors in Iranian students' English writings. Iranian EFL Journal, 8(2), 143-157.

[40] Shahhoseiny, H. (2015). A study of errors in the paragraph writing of elf learners: A case study of first year translation students at university of applied science and technology in bushehr, Iran. . Theory and Practice in Language Studies, 5(6): 1307-12.

[41] Solati, A. (2014). Psycholinguistic Sources of English Spelling Errors. International Journal of English and Education, 3(2), 37-51.

[42] Solati, A. (2016). Persian Nursery Students' Strategies in Using English Present Simple Tense. International Journal of Humanities and Cultural Studies, 3(2), 1681-1695.

[43] Tafazoli, D., Golshan, N., \& Piri, S. (2013). The frequency taxonomy of syntactico-morphological errors in Persian-English translation based on contrastive analysis and error analysis. Journal of Academic and Applied Studies, 3(10), 13-21.

[44] Tajareh,M.J \& Khodareza,M. (2015). The Effect of Error Analysis on Iranian Intermediate EFL Learners of L2 Adjective Knowledge. Journal of Teaching English Language Studies, 3 (4), 7-20.

[45] Varshney, RL. (1998). An Introductory Text Book of Linguistics and Phonetics. Student Store: Rampur Bagh, BAREILLY243001.

[46] Wilkins, D.A.(1999). Applied Linguistics. In Spolsky, B. (ed) Concise Encyclopedia of Educational Linguistics. Amsterdam: Elsevier; 6-17.

[47] Yousefi, S., Soori, A., \& Janfaza,A. (2014). Common Preposition Errors Committed by Iranian Students. International Journal of Applied Linguistics \& English Literature, 3(3), 1-9.

[48] Yousefi, S. (2018). The Study of Written Errors of Iranian EFL Pre-university Learners: A Case Study. Linguistic and Literary Broad Research and Innovation, 7 (1), 46-54.

Ali Akbar is Associate Professor of English Language Teaching at the Bushehr University of Medical Sciences, Bushehr, Iran. He has completed M.A. in English Language Teaching at the Aligarh Muslim University in 2003 and PhD in English Language Teaching at the Mysore University in 2010 in India He is the author of many books in the field of Applied Linguistics and English Language Teaching and published more than sixty articles in various Journals of English Language Teaching and Linguistics.

Farhad Pakdel is an English Language teacher at Department of English, Faculty of Paramedical Sciences, Shiraz University of Medical Sciences, Shiraz, Iran. 